\title{
Estimation of Curie Point Depth (CPD) across the Pan African Belt in Northern Cameroon from Aeromagnetic Data
}

\author{
Jean Daniel Ngoh', Théophile Ndougsa Mbarga',2, Kevin Mickus³, \\ Yara Tarek ${ }^{4}$, Tabod Charles Tabod ${ }^{1,5}$ \\ ${ }^{1}$ Postgraduate School of Science, Technology and Geosciences, University of Yaoundé I, Yaoundé, Cameroon \\ ${ }^{2}$ Department of Physics, Advanced Teachers' Training College, University of Yaoundé I, Yaoundé, Cameroon \\ ${ }^{3}$ Department of Geography Geology and Planning, Missouri State University, Springfield, MO, USA \\ ${ }^{4}$ Exploration Department, Egyptian Petroleum Research Institute, Cairo, Egypt \\ ${ }^{5}$ Faculty of Science, University of Bamenda, Bambili, Cameroon \\ Email: theopndougsa@gmail.com,jdngoh@gmail.com
}

How to cite this paper: Ngoh, J.D., Mbarga, T.N., Mickus, K., Tarek, Y. and Tabod, T.C. (2020) Estimation of Curie Point Depth (CPD) across the Pan African Belt in Northern Cameroon from Aeromagnetic Data. Open Journal of Earthquake Research, 9, 217-239.

https://doi.org/10.4236/ojer.2020.93013

Received: December 19, 2019

Accepted: April 6, 2020

Published: April 9, 2020

Copyright $\odot 2020$ by author(s) and Scientific Research Publishing Inc. This work is licensed under the Creative Commons Attribution International License (CC BY 4.0).

http://creativecommons.org/licenses/by/4.0/

\section{(c) (i) Open Access}

\begin{abstract}
The depth to the Curie isothermal point (CPD) was estimated using aeromagnetic data from northern Cameroon. The CPD was estimated using a two-dimensional power density spectral analysis of nineteen $30 \times 30 \mathrm{~km}$ blocks over a series of Neoproterozoic lithologies associated with the Pan African orogeny. The results show that there are two main regions characterized by the CPD analysis: 1$)$ Shallow depths $(\sim 6.37-10.09 \mathrm{~km})$ which are located in several regions including the northern portions of the study area (toward the regions of Hina Marbak, Gawel and northern Moutouroua), the southeast (Kaele region), the south (Guider) and the southwest (Mayo Oulo), and 2) deeper depths ( 10.68 $-13.72 \mathrm{~km})$ are located in the northeast (Mindif) and southwest (southern Moutouroua, Guider and Bossoum). The shallow depths can be related to two tectonic regimes: 1) the West-Central African Rift System with northeast-trending strike-slip faults emanating from the Gulf of Guinea and 2) the Cameroon Volcanic Line. However, the ultimate source of these shallow regions is interpreted to be related to the Cameroon Volcanic Line based on low seismic velocities imaged by recent broadband seismic studies which are concentrated along the northeast-trending strike-slip faults. An additional finding using the CPD depths, a Curie isothermal temperature of $580^{\circ} \mathrm{C}$ and a one-dimensional heat flow model, was heat-flow values ranging from 105.68 to $227.63 \mathrm{~mW} / \mathrm{m}^{2}$, which are above average global heat flow values and are therefore indicative of potential geothermal resources.
\end{abstract}




\section{Keywords}

Magnetic Anomaly, Spectral Analysis, Curie Point Depth, Geothermal Gradient, Heat Flow

\section{Introduction}

The thermal structure of the lithosphere is required for many geodynamic investigations, including the deformation of rocks, boundaries of mineral phase changes, and rates of geochemical reactions [1]. Geothermal gradients are commonly estimated from near-surface heat-flow measurements, but heat-flow measurements are commonly unavailable [2] [3], are distributed randomly, and may be affected by local thermal anomalies. In Cameroon, there are no heat flow data and the nearest heat flow data publicly available is in northern Nigeria. In regions where heat-flow data are sparse or unavailable, geophysical and geochemical methods can be used to estimate the thermal structure. For the geophysical methods, one can use magnetotellurics, magnetics, and seismic velocity to indirectly determine the presence of high heat flow values. Magnetotellurics and seismic velocity only indirectly infer the presence of higher temperatures by low electrical conductivities or low seismic velocities but do not provide temperature estimations. The magnetic method can determine the depth to the Curie point depth (CPD) where these depths can be used to estimate the regional heat flow [4].

The CPD is the bottom of a magnetic susceptibility source where the magnetic minerals lose their permanent magnetism at a temperature of approximately $580^{\circ} \mathrm{C}$ for magnetite which is the most common magnetic mineral. Magnetic anomalies can be used to study magnetic susceptibility structure above the CPD and the depth of the magnetic susceptibility sources [5]. Once the CPD is estimated, the geothermal gradient can be determined and used to estimate the heat flow using commonly accepted thermal properties of the lithologies in a given region. The use of aeromagnetic data to estimate the CPD is not new and has been used in various tectonic environments, either by using spectral methods or forward and inverse modelling of magnetic anomalies. In the spectral methods, there are a wide variety of techniques including calculating the spectrum of an anomaly using one-dimensional (1D) spectral methods [6], using two-dimensional (2D) spectral methods over a region of magnetic data [7] [8] or fractal methods based spectral methods [9]. In the forward and/or inverse methods, one can use $2 \mathrm{D}$ methods to model isolated anomalies [10] or three-dimensional (3D) inversion of magnetic anomalies [11] [12] to determine the bottom of magnetic susceptibility sources. One must remember with all of these methods, that one is determining the bottom of a magnetic susceptibility source and the solutions must still be assessed with outside geological and geophysical constraints to determine if the value obtained for the bottom of the source is lithological or related to 
temperature [13].

Magnetic studies in Cameroon have generally focused on regional geological structures [14] [15], oil and gas exploration [16], and mineral exploration [17]. There have been many tectonic studies that have used geological [18], gravity [19] and seismic [20] [21] data to study the tectonic evolution of Cameroon but most have mainly been involved investigation the Cameroon Volcanic Line (CVL). To date, there have been no studies involving the determination of the CPD or heat flow studies within Northern Cameroon.

In this study, we apply the fractal-based spectral method to magnetic anomalies over the NeoProterozoic Pan African region that has been affected by both the Mesozoic rifting of the West-Central African Rift System (WCARS) and the volcanism of the CVL in northern Cameroon to estimate the depth to the bottom of magnetic sources throughout this region. These depths will be further analysed to determine how they are related to the CDP and will be the first heat flow estimates reported for northern Cameroon. Furthermore, these magnetic anomalies, depths to the bottom of the magnetic susceptibility sources and the heat flow estimates will be used to infer lithospheric structures related to the Pan African orogeny.

\section{Materials and Methods}

\subsection{Geological and Tectonic Setting}

The tectonic setting of north-western Cameroon includes Pan African collision tectonics [14], Cretaceous rifting forming the WCARS [22] [23] and the CVL [24]-[31]. The dominant outcropping lithologies of north-western Cameroon are Proterozoic metamorphic, igneous and sedimentary units related to the Pan African orogeny of central Africa (Figure 1(a)). This orogeny consists of a mobile belt formed by the collision of several Precambrian terranes [26]. The Pan African belt in Cameroon is bordered on the south by the Congo Craton and by the Benue Trough on the north-northwest. The belt was formed by tectonic interactions of portions of the West African and Congo Cratons [26] (Figure (b)). These interactions are first represented by eastward dipping subduction in eastern Cameroon followed by a collision between the Nigerian Shield and the West African Craton [14]. However, the tectonic evolution along the northern border of the Congo Craton still rises questions due to the lack of oceanic rocks, but structural and geochemical evidence points to a collisional boundary [27]. This lack of agreement has led to a number of different tectonic models that all involve collision between various blocks [28] [29]. Additionally, at least two major strike-slip tectonic episodes have been reported that are neither coeval nor post-date the major collisional events [26] but are most likely related to the collision between the Congo Craton and some blocks to the northwest of the craton.

The Pan African belt in Cameroon consists of three main lithological units: 1) the Poli-Lere Group, 2) the Adamawa Domain and the 3) Yaounde Group [26] (Figure 1(a)). Of these, the Poli-Lere Group is the most prevalent within the 
study area (Figure 1(a)) with the Adamawa Group occurring in the southern portion of the study area. The Neoproterozoic Poli-Lere Group consists of volcanic and sedimentary origin medium- to high-grade schists and gneisses, formed in a magmatic arc context probably within a back-arc basin [29] and that pre-, syn- and post-Pan African tectonic calc-alkaline granitoids [30]. Post-Pan African tectonic alkaline granitoids contain mafic and felsic dykes that are crosscut by intrusive granites and syenites. These intrusions intrude the schists and gneisses, and form a NNW-trending line of batholiths [14]. Overlying the above units are unmetamorphosed sediments and volcanic rocks contained in several small basins [17] [31].

Three tectonic events affected the structural development of northern Cameroon, particularly the Poli area. These include a crustal shortening and thickening event caused by collision between Neoproterozoic blocks followed by syn to post-orogenic shear tectonic movements [26]. The crustal shortening event is seen as gentle folding outcropping in isoclinal folds with flat-lying foliations which were formed by thrust faulting (Figure 1(a)) [26]. Later compressional deformation formed vertical and NNE-trending foliations, and tight upright to recline folds [32].

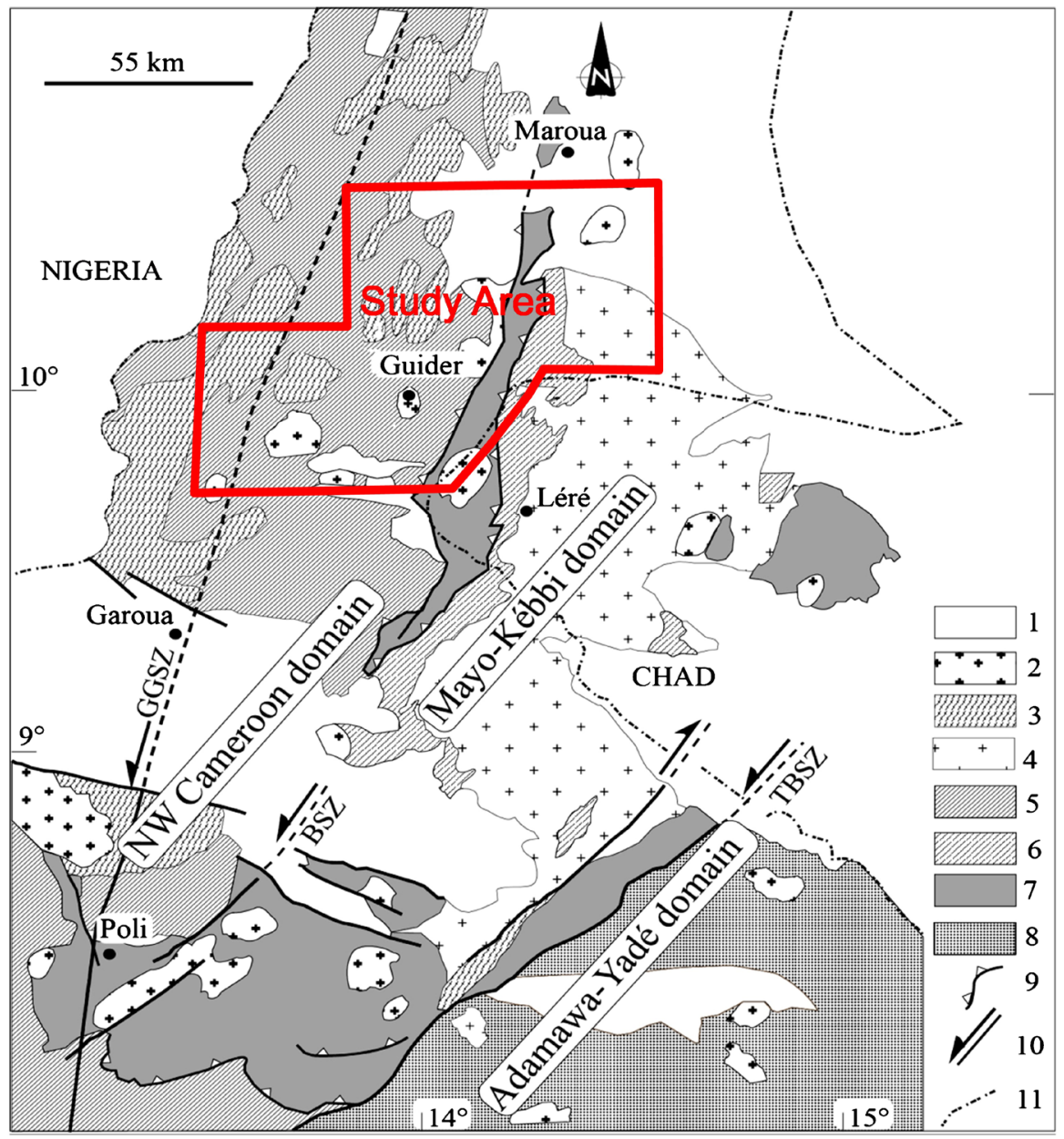

(a) 


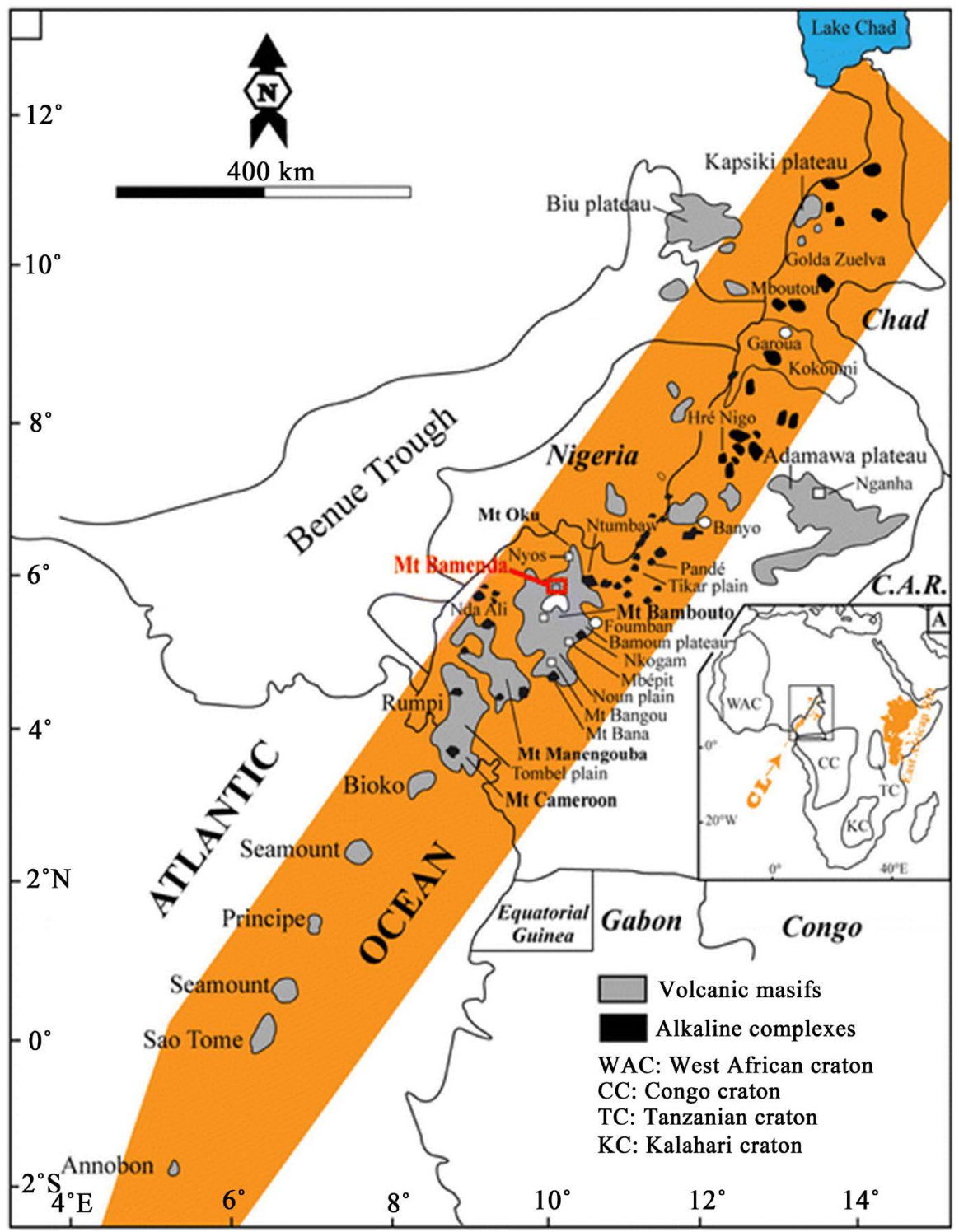

(b)

Figure 1. (a) Simplified geologic map of the study area (modified from Penaye et al., 2006): (1) Post-Pan-African sediments; (2) Late to post-tectonic Pan-African granitoids; (3) Syntectonic granite; (4) Mayo-Kebbi batholith: tonalite, trondhjemite and granodiorite; (5) medium- to high-grade gneisses of the NW-Cameroon domain; (6) Mafic to intermediate complex of the Mayo-Kebbi domain (metadiorite and gabbrodiorite) and amphibolite; (7) Neoproterozoic low- to medium-grade volcano-sedimentary sequences of the Poli-Léré Group; (8) Remobilized Palaeoproterozoic Adamawa-Yadé domain; (9) Thrust front; (10) Strike slip fault: TBSZ = Tcholliré-Banyo shear zone; GGSZ = GodéGormaya shear zone; BSZ = Balche shear zone; (11) State border. (b) Location of study area (outlined in yellow) along the Cameroon Volcanic Line (adapted after Pierre et al., 2017). The orange region is the location of the Cameroon Volcanic Line (CL). Inset shows the location of the map within Africa with the orange region in east Africa showing the location of similar aged volcanic units.

The tectonic phase of compression and late stage shear zone development was followed by NE-SW to N-S sinistral shear zones. The Tchollire-Banyo (TBSZ), 
Gode-Gormaya (GGSZ), and Balche (BSZ) shear zones are the major sinistral shear zones that are mainly represented by mylonites (Figure $1(\mathrm{a})$ ). The BSZ is classified by a secondary shear zone that cuts across the GGSZ but these are considered coeval with the NE-trending shear zones despite trending in a different direction [14].

The WCARS is a series of extensional and transtensional basins that extend from Nigeria and Cameroon eastwards into Chad through Kenya and northwards through Lake Chad into southern Algeria [23]. These basins were active [22] and, in Nigeria and Cameroon are represented by the thick clastic sediments of the Benue Trough (Figure 1(a), Figure 1(b)). Within the study area, the Cretaceous clastic sediments [33] and alkaline plutonic and volcanic rocks [34] are scattered throughout the study area (Figure 1(a)). The origin of the alkali igneous rocks is controversial, but most models are related to one or two hot spots in the Mesozoic [34].

The CVL (Figure 1(b)) overlies the Proterozoic basement in Cameroon [21] and covers over a $1600 \mathrm{~km}$ long Y-shaped trend of Cenozoic volcanoes that extend to the southern extent of the study area (Figure 1(b)). These volcanoes and sub-volcanic complexes [24] trend from the ocean-continent boundary in the Gulf of Guinea into the northern Cameroon. The volcanoes consist of mainly alkali basalts and some more evolved phonolites and trachytes with an inferred asthenospheric source [21]. Seismic studies indicate that low velocity nearly vertical P- and S-wave zones extend to at least $300 \mathrm{~km}$ in depth beneath the CVL, suggesting that edge flow convection against the Congo Craton may be responsible for these anomalies [20] [25]. These low velocity zones are more prevalent in western and northwestern Cameroon implying that these regions might be more susceptible to future volcanic eruptions.

\subsection{Aeromagnetic Data}

A series of aeromagnetic surveys were carried out in 1970 by SURVAIR with a flight height above the topography of $235 \mathrm{~m}$ and $750 \mathrm{~m}$ flight line spacings oriented at $\mathrm{N}^{\circ} 135$. Each individual survey was corrected for diurnal variations and was gridded into one coherent dataset. Then the regional magnetic field of the Earth or the IGRF (International Geomagnetic Reference Field) was removed from the dataset to produce a residual magnetic dataset. Then the residual magnetic dataset was gridded at a $0.75 \mathrm{~km}$ spacing interval and displayed as a color image (Figure 2). Next, the gridded TMI data were reduced to the equator (RTE) using inclination and declination angles of the IGRF of January 1, 1970 of $-1.01^{\circ}$ and $-3.96^{\circ}$, respectively. The RTE anomaly map (Figure 3 ) contains both small wavelength anomalies, high amplitude anomalies formed by magnetic lithologies at the surface or at depths near the surface, and longer wavelength anomalies related to deeper magnetic sources. To amplify the effect of the deeper source or longer wavelength anomalies, the RTE data were upward continued to $1 \mathrm{~km}$ above the Earth's surface. Figure 4 shows the upward continued RTE map. 


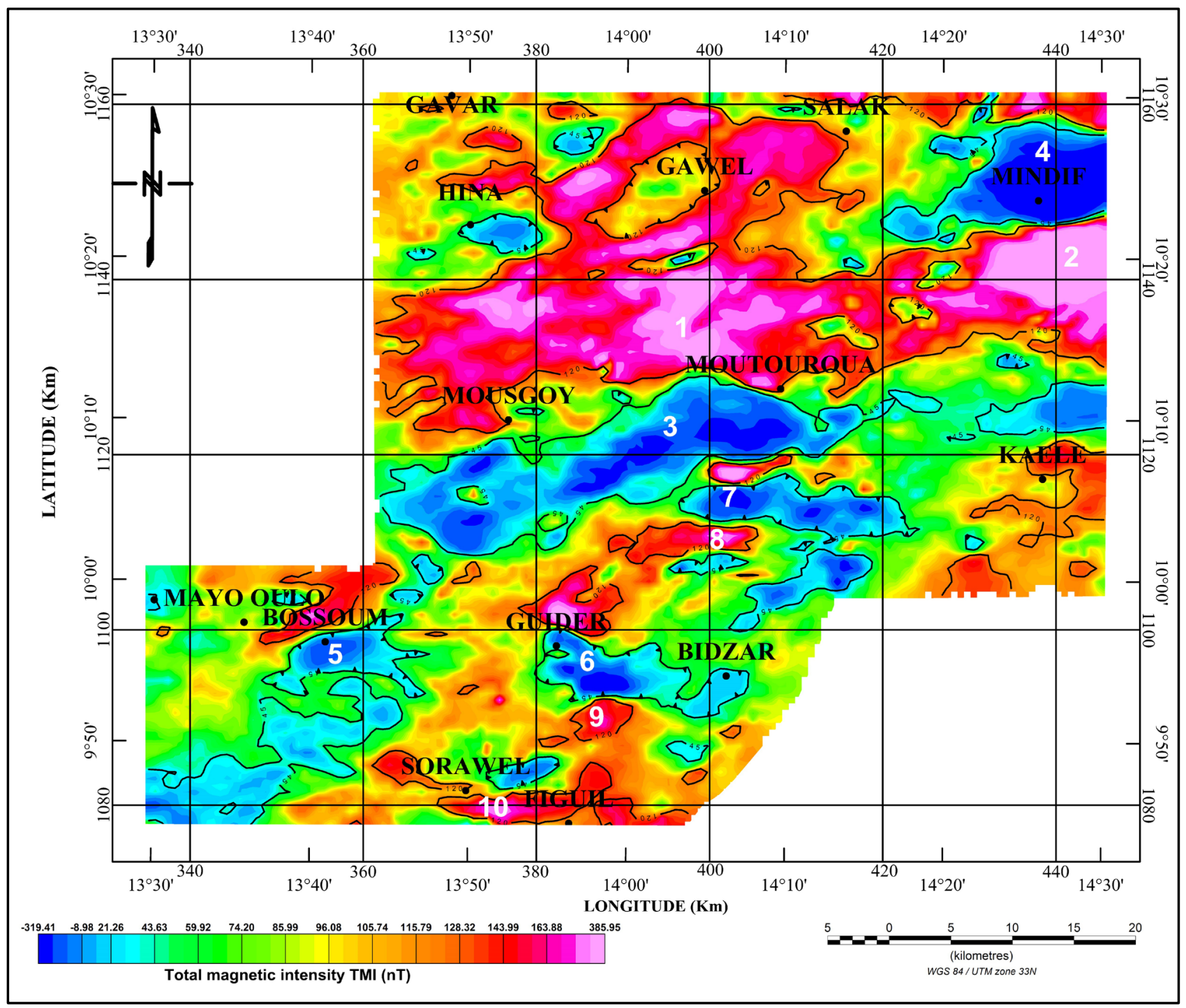

Figure 2. Total magnetic anomaly intensity (TMI) map of study area. Names and locations mentioned in the text and are located on all subsequent anomaly maps.

\subsection{Methodology}

\subsubsection{Spectral Analysis}

Numerical modelling of magnetic data has been used to determine the depth of magnetic interfaces including the Curie point depth (CPD) [35]. Spectral methods involve a number of different methods [4] [6] [36]. In either case, the 2D power spectrum methods are the most used methods in analysing Curie Point Depths and will be used in our study as [35] showed that these methods are more appropriate for the analysis of regional magnetic anomalies than forward and inverse modelling. While all the above methods can determine a bottom of a magnetic source, small-scale variations of theses depths make it difficult for them. This is especially true when using the spectral methods as the maximum depth of a magnetic source is a dependent on the size of the analyzed region [9]. The $2 \mathrm{D}$ power spectrum technique [8] [36] [37] was used to estimate the maximum 


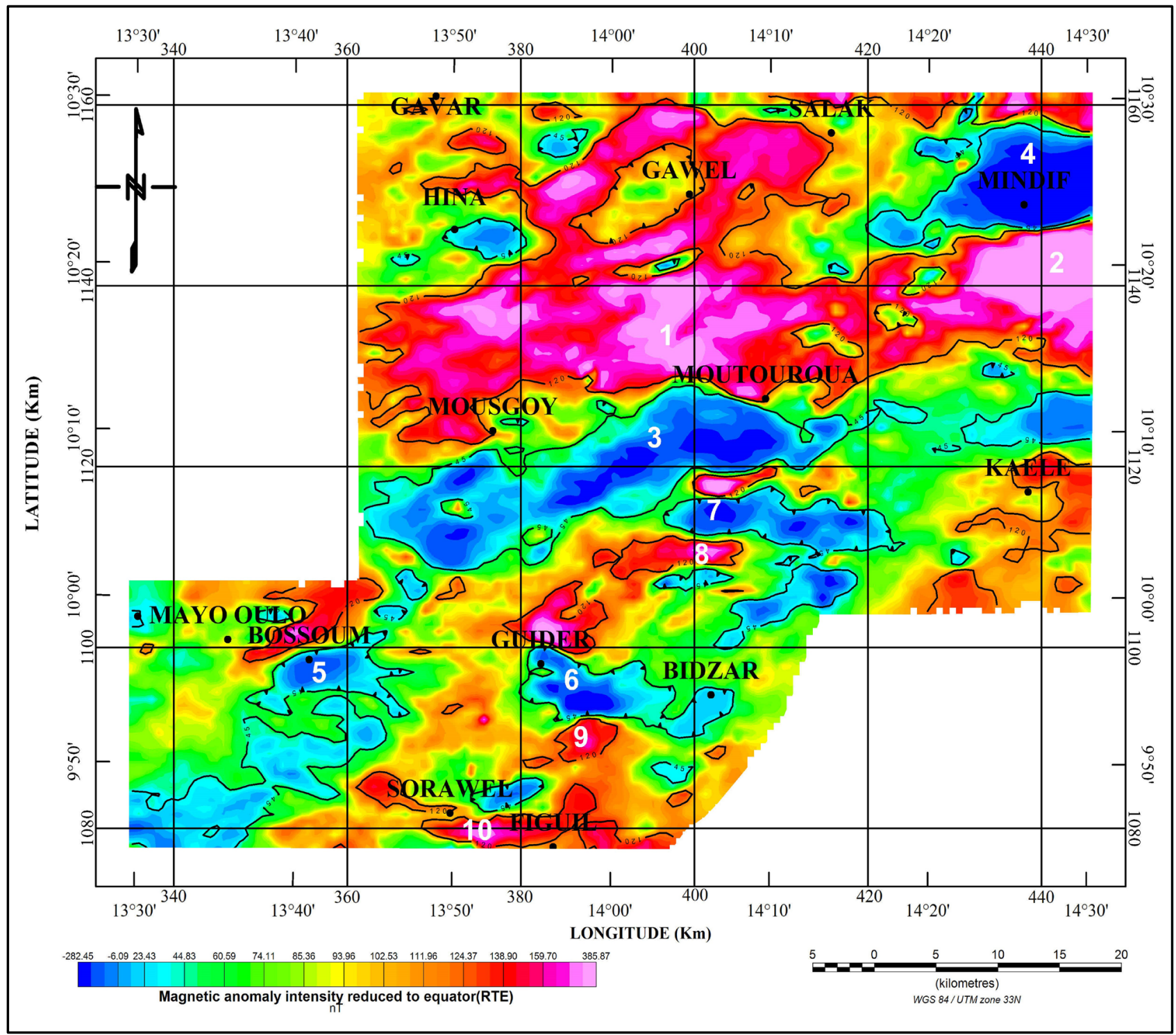

Figure 3. Total magnetic anomaly intensity reduced to equator map of study area. The black and white numbers are anomalies that are discussed in the text.

depth of magnetic sources.

Following the steps done by [4] [36], the depth $\left(Z_{b}\right)$ of the magnetic susceptibility source can be estimated using:

$$
z_{b}=2 z_{c}-z_{t} \text {. }
$$

where $z_{t}$ and $z_{c}$ are, respectively, the depth to the top and the depth to the centroid of the magnetized source. This depth can be related to the bottom of magnetically susceptible minerals or the CPD.

\subsubsection{Heat Flow Estimates from CPD}

One of the by-products of determining CPDs is that one can estimate temperature gradients and thus the heat flow over a region. This is probably the only geophysical method to determine the regional heat flow when there are no actual 
heat flow estimates from deep drill holes. The estimates of heat flow from the CPD analyses depend on the temperature used for Curie point and for the most geological environment, magnetite with a Curie temperature which is variable [38]. The $1 \mathrm{D}$ conductive heat flow equation using a constant gradient temperature was used to determine the heat flow. However, using this equation will only provide a first-order estimation of the heat flow [12] but in regions without drill hole determined heat flows, using the CPD is the best option. Fourier's law which describes $1 \mathrm{D}$ conductive heat movement can be expressed as:

$$
Q=k *\left(\frac{\mathrm{d} T}{\mathrm{~d} z}\right)
$$

where $Q$ is the heat flow and $\mathrm{k}$ is the coefficient of thermal conductivity.

Equation (2) assumes that the temperature gradient $(\mathrm{dT} / \mathrm{dz})$ is constant. The geothermal gradient the $\mathrm{CPD}\left(\mathrm{Z}_{\mathrm{b}}\right)$ and the surface can be defined [39] by:

$$
T_{C}=z_{b} *\left(\frac{d T}{d z}\right)
$$

where $T_{c}$ is the Curie temperature.

The next step is determining how the geothermal gradient is related to the heat flow $(Q)[40]$ :

$$
Q=k *\left(\frac{T_{C}}{z_{b}}\right)
$$

The Curie temperature is dependent on the magnetic mineralogy of the subsurface lithologies. The accepted value of the Curie temperature of magnetite is approximately $580^{\circ} \mathrm{C}$, however, an increase of Ti within titanomagnetite causes the Curie temperature to be lowered [41]. Based on the increase of pressure with depth [42], it was suggested that magnetite might have a Curie temperature of about $600^{\circ} \mathrm{C}$. However, the average Curie temperature may be as low as $450^{\circ} \mathrm{C}$ based on comparing Curie depths determined from magnetic data and the associated calculated temperature gradients [43]. The above temperature variations for the Curie point for magnetite suggest that an estimate of the heat flow will be variable from the analysis of CPDs. However, using $580^{\circ} \mathrm{C}$ in regions with scattered heat flow estimates from drill holes have shown that this temperature can provide reasonable regional heat flow estimates [11] [12]. In addition to estimating a Curie temperature, the thermal conductivities $(\mathrm{k})$ of the lithologies must be estimated to determine the heat flow. Within the northwest of Cameroon, the most common lithologies are metamorphic schists and gneisses, and granites with have thermal conductivities between $1.3-2.9$ and $2.4-3.8$ $\mathrm{W} \cdot \mathrm{m}^{-1} \cdot \mathrm{K}^{-1}$, respectively $[40]$.

\section{Results and Discussion}

\subsection{Total Magnetic Anomaly Intensity Reduced to the Equator (RTE)}

The RTE magnetic map (Figure 3) has anomaly values ranging from approxi- 
mately -77 to $300 \mathrm{nT}$. These values are in general reflected by variations in the lateral variations in the amount of magnetite within the crustal rocks. Within northwestern Cameroon, these anomalies can be usually correlated with the Proterozoic granitic and metamorphic lithologies including metavolcanics, metaigneous rocks, gneisses and schists (Figure 1(a)). The RTE map contains mainly northeast trending minima and maxima anomalies that are roughly parallel to the strike-slip tectonic episodes that related to the Proterozoic collisional events [26]. The most prominent anomalies are a series of large wavelength, low amplitude magnetic maxima (anomalies 1 and 2) and slightly higher amplitude magnetic minima (anomalies 3 and 4 ) in the northern portion of the map (Figure 3). The magnetic maxima are caused by lithologies with lower magnetic susceptibility content. The area of anomalies 1 and 2 occur over the medium to high grade gneisses of the NW Cameroon terrane and post Pan African sediments (Figure 1). The extent of this large amplitude magnetic maxima implies that the magnetic susceptibility of the gneisses is relatively low with some regions (small wavelength maxima within the region of anomaly 1 ) containing higher susceptibilities. This could be due to higher grade gneisses or isolated bodies of mafic metaigneous rocks.

The upward continued RTE map shown in Figure 4(a) exhibits a similar pattern of high and low magnetic anomalies that are seen in Figure 3. The upward continued RTE map is characterized by anomalies values ranging from about -164.47 to $288.31 \mathrm{nT}$. The upward continued RTE map is basically a smoothed version of the RTE map and contains prominent negative (long wavelength) anomalies distributed at the northeastern, central and southern parts of our study area. The persistence of the prominent anomalies with large wavelength, low amplitude magnetic maxima (anomalies 1 and 2) and slightly higher amplitude magnetic minima (anomalies 3 and 4) observed in the northern portion of the map (Figure 4(a)) which indicates that they are associated to deeper structures. In addition, the upward continued RTE map shows attenuated anomalies (anomalies 5, 8, 9 and 10) that are still related to upper crustal lithologies. However, all these anomalies are also present on the RTE map (Figure 3).

\subsection{Curie Point Depth and Heat Flow}

The CPD's and depths to the bottom magnetic sources were determined using the methods of [4] where a 2D radial power spectra analysis of the upward continued RTE data was used (Figure $4(\mathrm{a})$ ) utilizing a $50 \%$ overlapping of $30 \times 30$ $\mathrm{km}$ square blocks, as is illustrated in Figure 4 (b). The study area was subdivided into twenty-one blocks. It is well known that the using of a small window width may produce an error in using the spectral methods in aeromagnetic interpretation [44]. Furthermore, it was showed that [12] window size is dependent on the depth to the bottom of a magnetic susceptibility source and that the window size should be two to three times the depths to be determined. Accordingly, the radial power spectra for different window widths were calculated, it is ranging 
from 10 to $55 \mathrm{~km}$ with a $5 \mathrm{~km}$ increase in window width and found that a $30 \times$ $30 \mathrm{~km}$ window best delineated depths between 6 and $13 \mathrm{~km}$. The $2 \mathrm{D}$ radial power spectrum (Figure 4(c)) of the upward continued RTE data for each window was then computed. Next, the long wavelengths of regional magnetic anomalies were removed using a first-order polynomial trend surface for each block, and the grids were expanded by $10 \%$ to lessen the edge effects of using the Fourier Transform in determining the power spectrum [45].

Following [4] [36] [37] and references therein, for each block, the depth to bottom of magnetic source in the present study is estimated in four main steps using [4] method:

1) compute the radially averaged power spectrum of the magnetic data;

2) firstly, pick two points to determine the slope on first spectrum (black line) in order to estimate the depth to the top of the magnetic source $\left(Z_{t}\right)$;

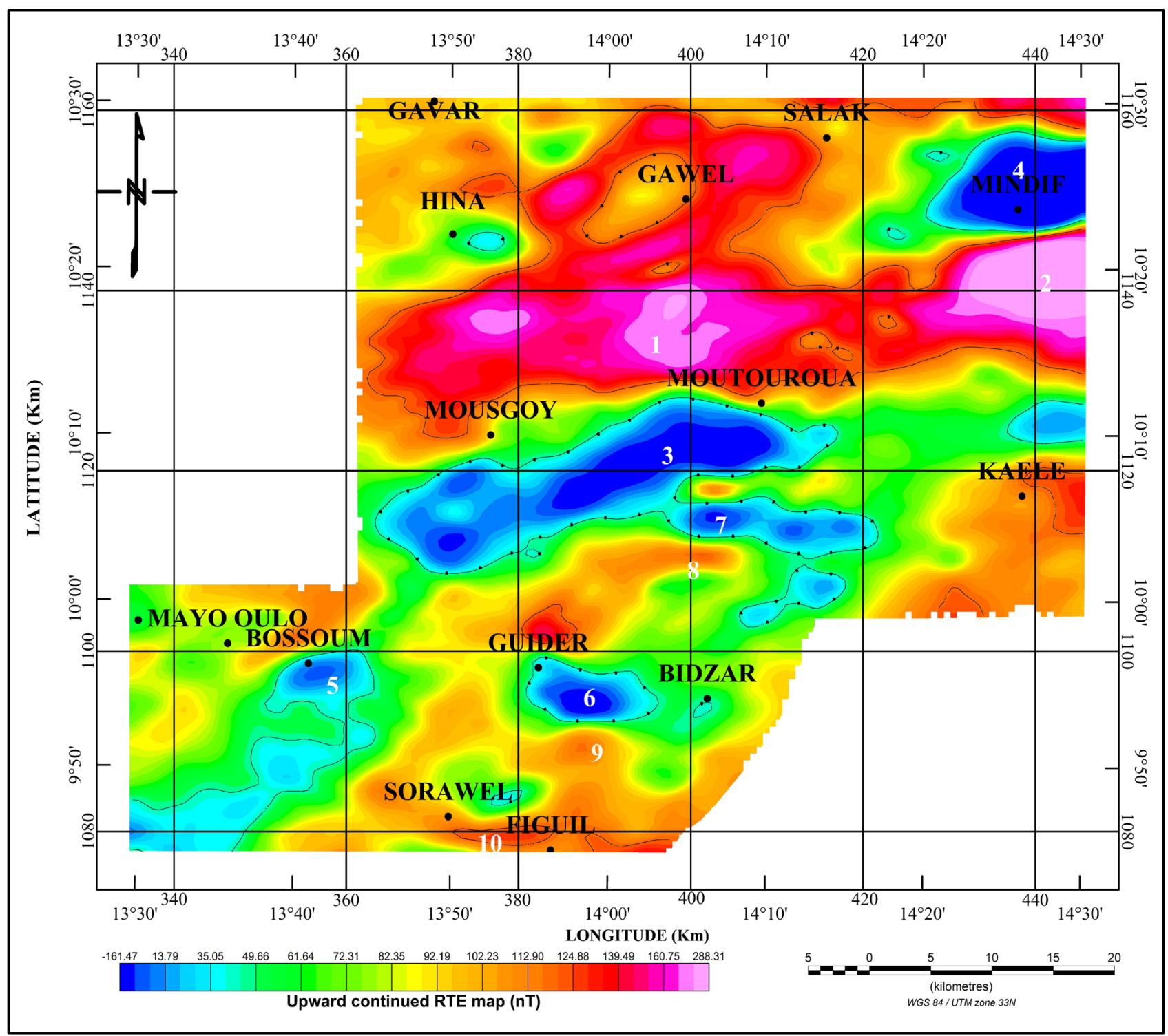

(a) 


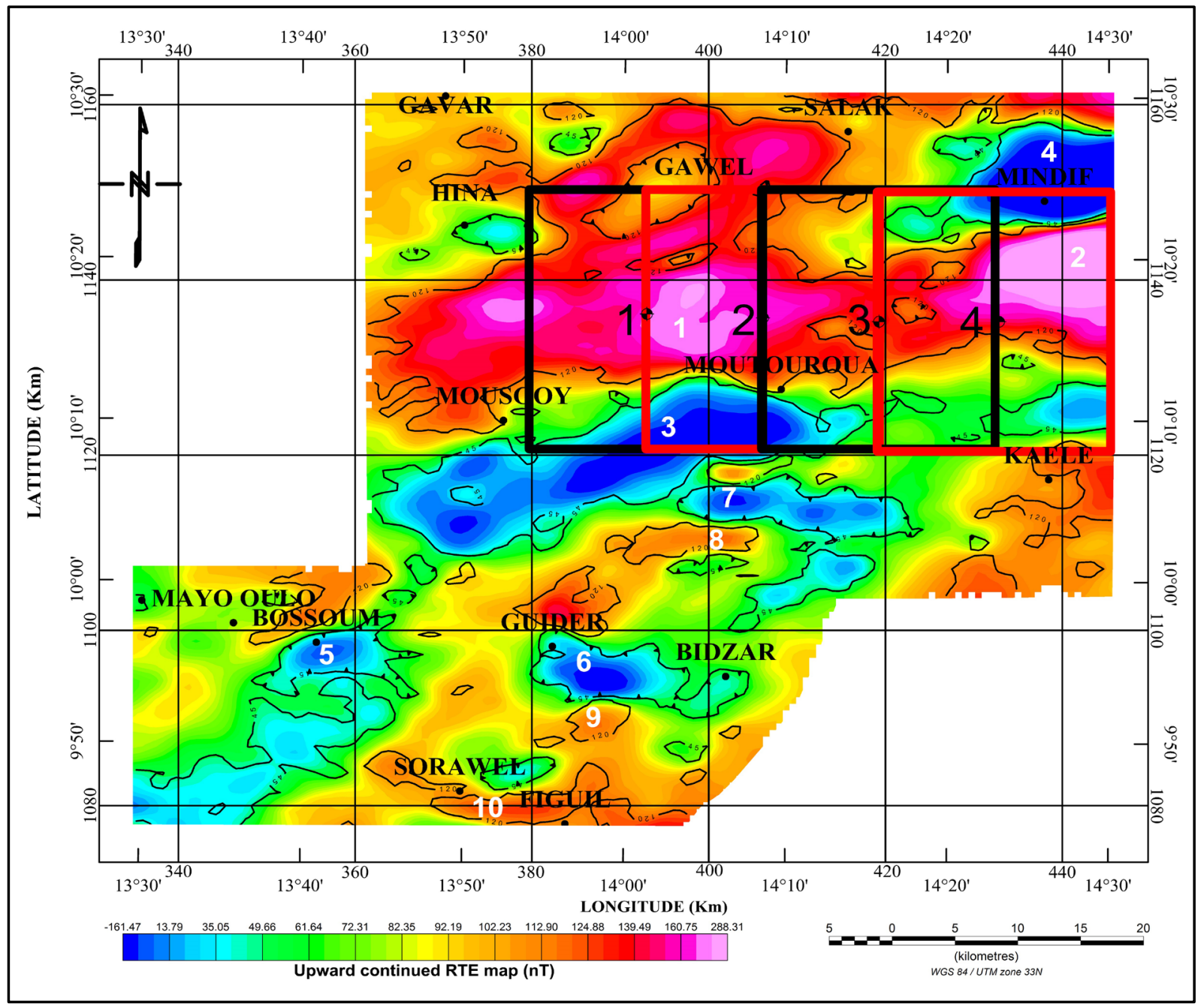

(b)

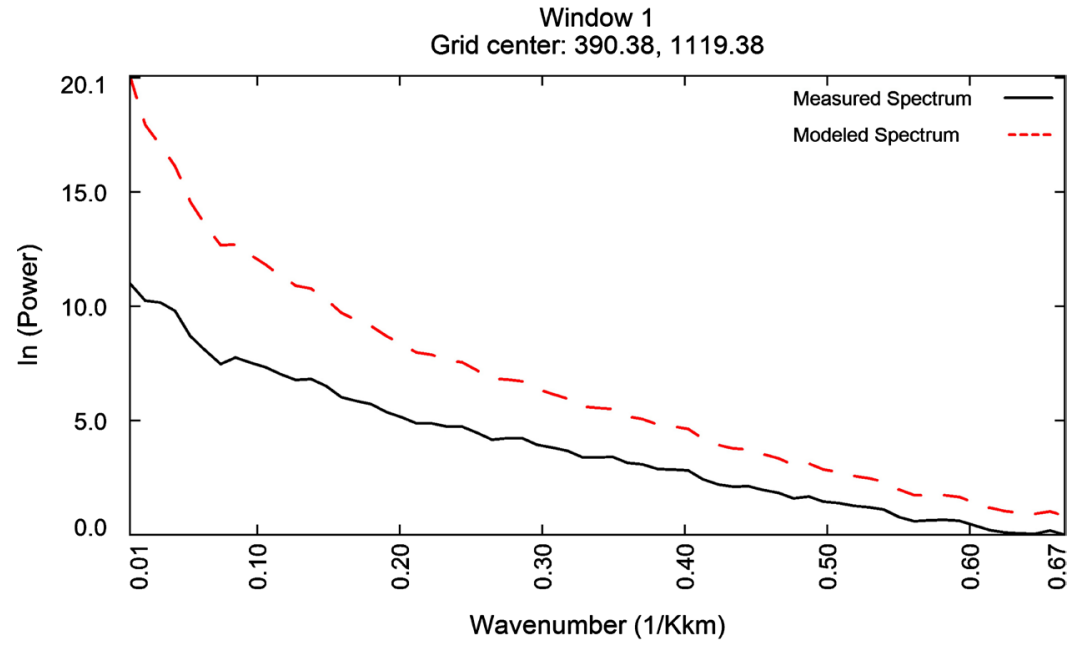

(c)

Figure 4. (a) The RTE map (Figure 3) upward continued to $1 \mathrm{~km}$ above the Earth's surface. The black and white numbers are anomalies that are discussed in the text. (b) The RTE map upward continued to $1 \mathrm{~km}$ above the Earth's surface, illustrating some selected overlapping blocks. (c) Computed radially averaged power spectrum with frequency-scaled spectrum for block 1 . 
3) afterwards pick two points to determine the slope on the frequency-scaled spectrum (red line) to estimate the depth to the centroid of the magnetic source $\left(Z_{c}\right)$

4) thus, deduce the depth to the bottom of the magnetic source $\left(Z_{b}\right)$ using relation (1).

The results of the power spectrum analysis are shown in Table 1, on which the heat flow and geothermal gradient were deduced using relation (2) and (4). The estimated depths to the centroid range from $4.06 \mathrm{~km}$ for block 13 to $9.74 \mathrm{~km}$ for block 9. However, the depths to the top of magnetic susceptibility sources ranged from 1.74 to $5.73 \mathrm{~km}$. Hence, the depths to the bottom of the magnetic susceptibility sources range (which was interpreted to be the CPD) from a minimum depth of $6.36 \mathrm{~km}$, to a maximum depth of $13.72 \mathrm{~km}$. The spectrally determined depths reflect the average depths beneath each block [46]. The ranges of the estimated depths to the top boundary of the magnetic sources are well correlated with the other regional work in and surrounding the study area

Table 1. Estimated CPD, geothermal gradients and heat flow for the 21 blocks in the study area.

\begin{tabular}{|c|c|c|c|c|c|c|c|}
\hline \multirow{2}{*}{ Block number } & \multicolumn{2}{|c|}{ Coordinates (UTM) } & \multirow{2}{*}{$\begin{array}{l}\text { Depth to Top } \\
(\mathrm{km})\end{array}$} & \multirow{2}{*}{$\begin{array}{c}\text { Depth to } \\
\text { Centroid }(\mathrm{km})\end{array}$} & \multirow{2}{*}{$\mathrm{CPD}(\mathrm{km})$} & \multirow{2}{*}{$\begin{array}{l}\text { Geothermal Gradient } \\
\qquad\left({ }^{\circ} \mathrm{C} / \mathrm{km}\right)\end{array}$} & \multirow{2}{*}{$\begin{array}{l}\text { Heat Flow } \\
\left(\mathrm{mW} / \mathrm{m}^{2}\right)\end{array}$} \\
\hline & Easting $(\mathrm{km})$ & Northing $(\mathrm{km})$ & & & & & \\
\hline bloc1 & 429.771 & 1145.118 & 5.73 & 8.06 & 10.39 & 55.82 & 139.55 \\
\hline bloc2 & 414.607 & 1145.118 & 5.35 & 7.68 & 10.01 & 57.94 & 144.85 \\
\hline bloc3 & 399.326 & 1145.118 & 3.40 & 5.72 & 8.04 & 72.13 & 180.35 \\
\hline bloc4 & 384.28 & 1145.118 & 3.43 & 4.90 & 6.37 & 91.05 & 227.63 \\
\hline bloc5 & 429.653 & 1130.072 & 3.83 & 6.15 & 8.47 & 68.47 & 171.19 \\
\hline bloc6 & 414.372 & 1130.307 & 4.97 & 7.29 & 9.61 & 60.35 & 150.88 \\
\hline bloc7 & 399.326 & 1130.307 & 4.68 & 7.28 & 9.88 & 58.70 & 146.76 \\
\hline bloc8 & 384.28 & 1130.307 & 3.93 & 6.25 & 8.57 & 67.67 & 169.19 \\
\hline bloc9 & 384.516 & 1115.496 & 5.76 & 9.74 & 13.72 & 42.27 & 105.68 \\
\hline bloc10 & 399.326 & 1115.496 & 5.59 & 9.56 & 13.53 & 42.87 & 107.17 \\
\hline bloc11 & 349.722 & 1092.692 & 3.63 & 7.16 & 10.69 & 54.25 & 135.64 \\
\hline bloc12 & 364.768 & 1092.692 & 3.84 & 7.81 & 11.78 & 49.23 & 123.09 \\
\hline bloc13 & 379.579 & 1092.692 & 1.74 & 4.06 & 6.38 & 90.90 & 227.27 \\
\hline bloc14 & 429.418 & 1120.433 & 4.47 & 6.79 & 9.11 & 63.66 & 159.16 \\
\hline bloc15 & 414.372 & 1120.198 & 5.11 & 9.08 & 13.05 & 44.44 & 111.11 \\
\hline bloc16 & 384.751 & 1092.692 & 2.71 & 6.68 & 10.65 & 54.46 & 136.15 \\
\hline bloc17 & 389.923 & 1095.278 & 2.21 & 6.47 & 10.73 & 54.05 & 135.14 \\
\hline bloc18 & 394.625 & 1100.685 & 3.61 & 7.58 & 11.55 & 50.21 & 125.54 \\
\hline bloc19 & 379.814 & 1145.588 & 1.94 & 4.27 & 6.6 & 88.00 & 219.69 \\
\hline bloc20 & 379.579 & 1130.542 & 5.62 & 9.59 & 13.56 & 42.77 & 106.93 \\
\hline bloc21 & 379.814 & 1115.731 & 5.29 & 7.27 & 9.25 & 62.70 & 156.76 \\
\hline
\end{tabular}


[18] [46] [47]. From seismic refraction studies, the maximum depth to the basement in the central sector of the WCARS is around $7 \mathrm{~km}$ [18].

Previous CPD studies [12] have shown that the CPD is related to the geological makeup of an area. The shallowest depth to the bottom of the magnetic susceptibility sources (CPD), ranging between 6.37 and $10.01 \mathrm{~km}$, is obtained within the blocks 2, 3, 4, 5, 6, 7, 8, 13, 14, 19 and 21. These blocks are located in different regions of the study area including the northern portion (Hina Marbak, Gawel and north of Moutouroua), the southeastern portion (Kaele), southern portion (Guider) and southwestern portion (Mayo Oulo). The majority of these areas (e.g., Hina Marbak, Gawel and north of Moutouroua) (Figure 1(a)) are located where Lower Cretaceous sediments outcrop. Numerous lineaments and shear zones are located in this region [15]. These shallow depths may be due to magmatic intrusions which could be related to the CVL, and the other shallow depths are likely due to the rifting related to the Benue Trough [48]. [47] showed that this region is mainly related to the CVL, although this region has been affected by a failed arm of the Benue Trough. The thermal effect of the igneous activity on the Cretaceous sedimentary basins and the basement complex, led to local thermal anomalies observed in the region [49]. [4] using Japan as an example showed that CPDs less than $10 \mathrm{~km}$ occur in volcanic and geothermal areas, between 15 - $25 \mathrm{~km}$ in island arcs, and deeper than $20 \mathrm{~km}$ in oceanic plateaus, while [12] showed that in Precambrian terrains these depths are greater than 15 $\mathrm{km}$.

From our analysis, four shallows (depths less than $10.38 \mathrm{~km}$ ) CPD regions: SCPD1, SCPD2, SCPD3 and SCPD4 can be identified. These regions might be related to elevated heat flow in the study area. SCPD1 is in the northwestern part of the study area and is located near the Hina-Gawel area where it trends in a northwest direction. SCPD2 is located in the eastern part of the study area and is located in the Kaele area, approximately trending north-south. SCPD3 is located in the southern portion of the study area near the Guider neighbourhoods where it trends approximately north-south. SCPD4 is located in the Mayo Oulo area and also approximately trends north-south. However, the shallower regions of SCPD1 and SCPD2 could also be considered as a separate shallow CPD regions as this region is split into two parts by a broad northeast trending of deeper CPD region centered at longitude $14^{\circ} 10^{\prime}$. This slightly deeper trend occurs over the mafic to intermediate metaigneous lithologies of the Mayo-Kebbi domain and the metavolcano-sedimentary units of the Poli-Lere Group (Figure 1(a)). This region also is the site of numerous thrust faults related to the collision tectonics of the Pan African belt and thus may be a region of thicker crust with lower heat flow values and may have been harder to rift during the formation of the Central African Rift system. The other shallow CPD regions are found in the SCPD3 and SCPD4 regions (Figure 5). These regions are adjacent to the inferred trend of the CVL and the elevated CPD may be related to magmatic activity within the CVL. 


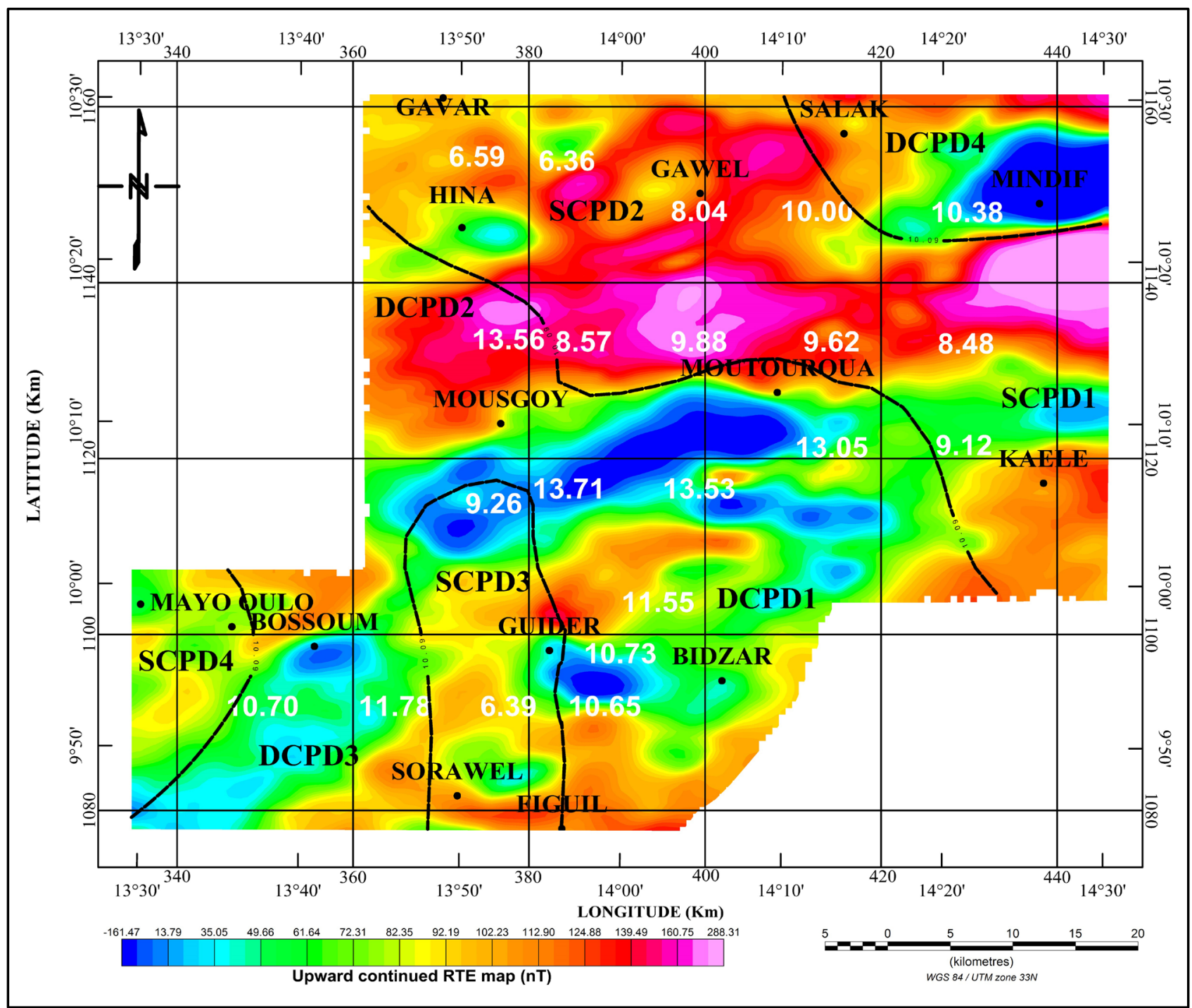

Figure 5. The CPD map outlining the shallow CPD regions (SCPD) and deep CPD regions (DCPD).

The deeper depths to the bottom of magnetic sources, ranging between 10.38 and $13.72 \mathrm{~km}$, is found in the northeast portion of the study area (DCPD4, Mindif region) and in the southwest (DCPD3, Moutouroua, Guider, Bossoum). DCPD4 is within the Cretaceous sediments related to the Benue Trough but lies along trend to the deeper values mentioned above related to the thrust zone with the Mayo-Kebbi domain. DCPD3 is in a region of syntectonic granites and medium to high grades gneisses of the NW-Cameroon domain (Figure 1). Additionally, two other deeper regions (DCPD1 and DCPD2) are seen on Figure 5. This northwest trending zone occurs mainly over the Neoproterozoic gneisses of the NW-Cameroon zone (Figure 1) suggesting that the shallow regions to the northeast and southwest are related to small isolated geothermal anomalies. Recently, the studies done by [50] in Mindif-Kaele area revealed potential geothermal reservoirs at Djangal and Moundjou, located in northeastern portion of the study area (SCPD1, Mindif neighbourhood), which is corroborated by the 
CPD regions.

The shallow CPDs in regions SCPD4 and SCPD3 (Figure 5) can be associated with regions that have been extended in the Mesozoic during the formation of the WCARS which formed the Benue Trough. Regions SCPD1 and SCPD2 are not so readily interpretable as these regions occur over Quaternary sediments and Proterozoic units (Figure 1). Seismic S-wave tomographic images locate these regions over low velocity zones indicating that these shallow regions may be related to magma in the subsurface. However, the S-wave tomographic images were constructed by 25 broadband stations covering the entire country of Cameroon [25] and do not have the resolution to image small-scale differences in the S-wave velocity structure. The S-wave tomographic results [25] indicate that the main zone of the CVL is underlain by deep low velocity zones, but in northern Cameroon the low velocity zones are of a smaller magnitude and cover isolated areas. The most prominent low velocity region, which occurs over the Cretaceous sediments, is correlated to shallow CPD regions SCPD3 and SCPD4. Additionally, the P-wave velocity images, which are less sensitive to partially melted material, indicate similar but more subtle trends than the S-wave results. The P-wave images also indicate small amplitude low velocity regions under our shallow CDP regions SCPD1 and SCPD2. This lack of correlation may be due to other factors other than thermal variations such as the wide spacing of the broadband stations, or that the northern low P-wave velocity zones are more indicative lithological variations at depth than the S-wave results. In fact, the shallow CDP regions seen in Figure 5 may represent regions of potentially higher magmatic and/or geothermal activity that cannot be imaged by widely spaced broadband seismic experiments. To determine that cause of our shallow depths, more detailed crustal scale seismic studies in the form of seismic refraction or closely spaced broadband stations, and/or magnetotelluric studies are needed to confirm if these regions are indeed related to geothermal activity. In contrast, the deeper CPD regions (DCPD1-4) may be related to thicker crust [51] or are regions with less Quaternary magmatic activity. The CPD depths occur in general trends which are consistent with the prevailing tectonic environment, where a series of NNW to NW-trending extensional basins occur, caused by the strain of NE to ENE trending strike-slip faults coming from the Gulf of Guinea [22].

The determination of the surface heat flow requires a CPD and a thermal conductivity of the most common lithologies in the region. For the thermal conductivity, $2.5 \mathrm{~W} \cdot \mathrm{m}^{-1} \cdot{ }^{\circ} \mathrm{C}^{-1}$ was used based on the average thermal conductivity values for Proterozoic lithologies [52]. Using the CPDs from Table 1 and a Curie isothermal point of $580^{\circ} \mathrm{C}$, a geothermal gradient was calculated. The heat flow values were then determined by multiplying the geothermal gradient by the thermal conductivity using equation 8 . The lowest heat flow value (105.68 $\left.\mathrm{mW} / \mathrm{m}^{2}\right)$ was obtained for block 9 and the highest heat flow value (227.63 $\mathrm{mW} / \mathrm{m}^{2}$ ) was obtained for block 4 (Table 1). The heat flow values are all greater than $100 \mathrm{~mW} / \mathrm{m}^{2}$ and worldwide heat flow values average between $80-100$ 
$\mathrm{mW} / \mathrm{m}^{2}$. Thus, our heat flow values indicate that northern Cameroon has geothermal anomalous conditions [53]. In particular, the regions with heat flow values greater than $180 \mathrm{~mW} / \mathrm{m}^{2}$ are indicative of regions with geothermal potential. The region with the greatest geothermal potential is found in the northern portions of the study area, particularly in the neighbourhood of Hina Marbak where the heat flow value was the highest. The study area exhibits two main potential geothermal areas which are characterized by low and high heat flow. The high heat flow values are concentrated around the Hina-Gawel, Kaele, Guider and Mayo Oulo areas (Figure 5). The results also show that shallow depths and the attendant high heat flow values may be related to the effects of large-scale tectonic events. In northern Cameroon, the most likely magma rising event is the formation of the volcanic material in the CVL that has risen along the northeast-trending strike-slip faults. The known volcanoes occur just to the south of the study area [24] but a recent broadband seismic study indicates that potentially partially melted material may exist in isolated areas in northern Cameroon [31]. Heat flow studies in other regions have shown that the heat flow in sedimentary basins the amplitude of the temperature effect is larger for thermal events within the basin (intrusions or diapirism) [54] and in Proterozoic metamorphic and igneous terranes where the lithologies have an average higher thermal conductivities [55]. This same reasoning applies that high heat flow found in northern Cameroon may be indicative of wide scale thermal events. Potential regions for geothermal exploration are regions characterized by high heat flow, high temperature gradient, and therefore shallow depths to the bottom of magnetic susceptibility sources [56].

Figure 6(a) and Figure 6(b) show the variations of the geothermal gradient and heat flow with the calculated CPDs, respectively. The geothermal gradient and heat flow decrease significantly with the deeper depths to the CPD. The results obtained also indicate that the geothermal gradients in this study area vary between 42.27 and $91.05^{\circ} \mathrm{C} / \mathrm{km}$; with an atypical maximum of $91.05^{\circ} \mathrm{C} / \mathrm{km}$ stands out in the in the neighbourhood of Hina Marbak.

\section{Conclusion}

Aeromagnetic data from northern Cameroon were investigated in order to determine the Curie point depth (CPD) and to aid in assessing the geothermal potential of the region. The CPDS were estimated using a $2 \mathrm{D}$ radially averaged power spectral method using $30 \times 30 \mathrm{~km}$ blocks of upward continued aeromagnetic data. The estimated CPDs indicate that depths vary from 6.37 to $13.72 \mathrm{~km}$. The results suggest that there are four regions of shallow CPDs with two regions in northern part of the study area and one in the southeast and one in the southwest portions of the study area. The southern shallow CPD regions correspond to a region of Cretaceous sediment formed by West-Central African Rift System and are along the northern extent of the still active Cameroon Volcanic Line which occurs above low S-wave velocity regions imaged by broadband 

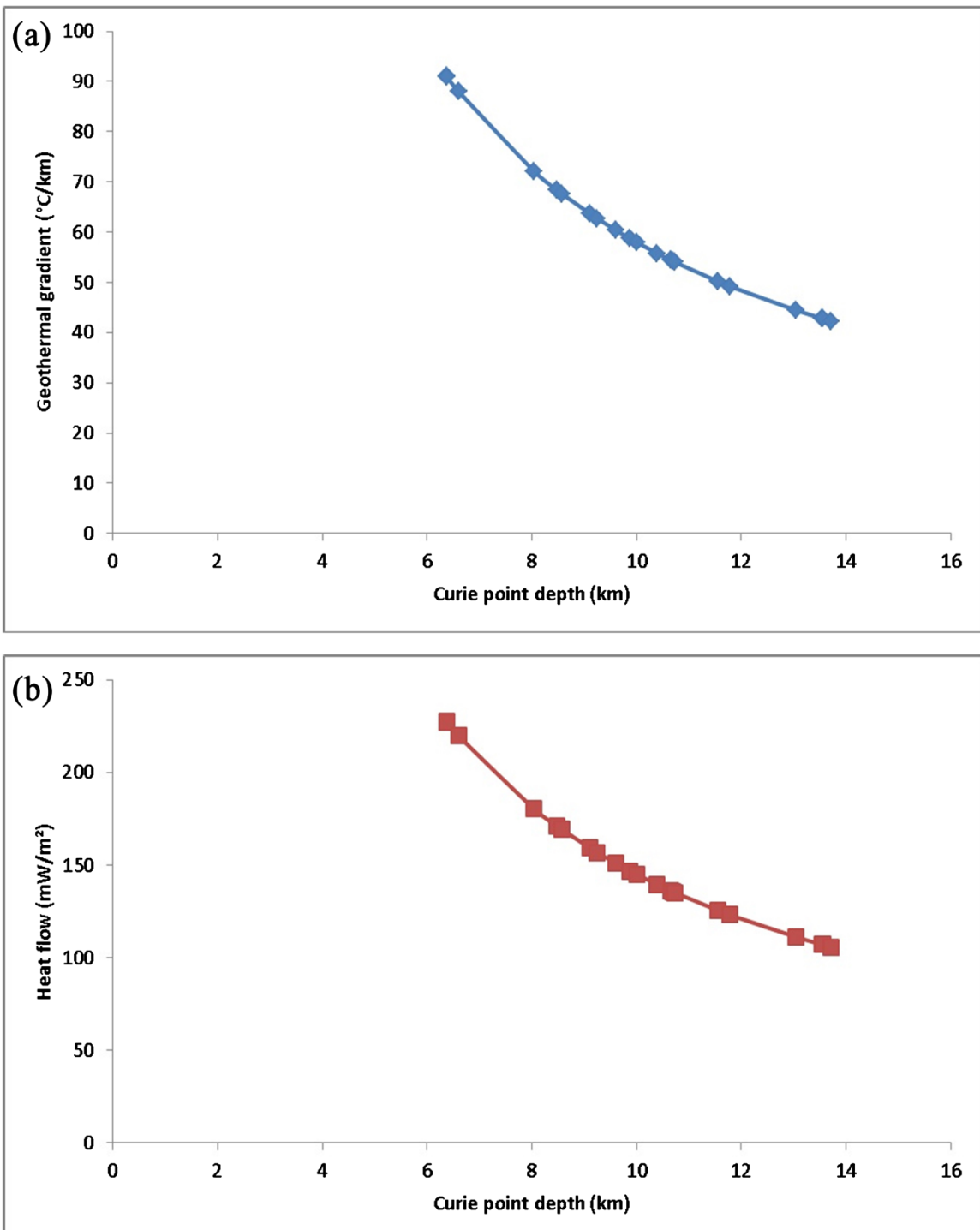

Figure 6. (a) The variation of geothermal gradient with the estimated Curie point depth. (b) The variation of heat flow with the estimated Curie point depth.

seismic studies. The northern shallow CPD zones occur over Proterozoic metamorphic and igneous lithologies but also occur above low P-wave velocity regions. Using the CPD and average thermal conductivity values, heat flow values ranged from 227.63 to $105.68 \mathrm{~mW} / \mathrm{m}^{2}$, which are considered above average global heat flow values. The regional trends observed in CPDs are thought to be related to magmatic activity associated with the Cameroon Volcanic Line and possibly to the strain being released by the northeast-trending strike-slip motions associated with the Benue Trough. Overall, the most important information's provided from this study, is existence of potential geothermal energy resources in terms as subsurface hot spots or geothermal reservoir, which could be a powerful source of renewable energy. On other hand, the estimation of the CPD values could be useful tool to explain hydrothermal activity or geodynamic processes in the study area, delineate zones with a favourable geothermal system. 
More details of geophysical investigations should determine further the geothermal potential of these high flow areas. These supplementary data may allow to accurately predict the economic strategies for exploitation of this potential geothermal energy resource in aiming to support the Gov't energy policies in the area.

\section{Conflicts of Interest}

The authors declare no conflicts of interest regarding the publication of this paper.

\section{References}

[1] Chapman, D. and Furlong, K. (1992) The Thermal State of the Lower Crust, In: Fountain, D., Arculus, R. and Kay, R., Eds., Continental Lower Crust, Developments in Geotectonics, Elsevier, ¡Amsterdam, 179-199.

[2] Nyblade, A. and Pollack, H. (1993) A Global Analysis of Heat Flow from Precambrian Terranes: Implications for the Thermal Structure of Archean and Proterozoic Lithosphere. Journal of Geophysical Research, 98, 12207-12218. https://doi.org/10.1029/93JB00521

[3] Artemieva, I. and Mooney, W. (2001) Thermal Thickness and Evolution of Precambrian Lithosphere: A Global Study. Journal of Geophysical Research, 106, 16387-16414. https://doi.org/10.1029/2000JB900439

[4] Tanaka, A., Okubo, Y. and Matsubayashi, O. (1999) Curie Point Depth Based on Spectrum Analysis of the Magnetic Anomaly Data in East and Southeast Asia. Tectonophysics, 306, 461-470. https://doi.org/10.1016/S0040-1951(99)00072-4

[5] Aboud, E., Salem, A. and Mekkawi, M. (2011) Curie Depth Map for Sinai Peninsula, Egypt Deduced from the Analysis of Magnetic Data. Tectonophysics, 506, 46-54. https://doi.org/10.1016/j.tecto.2011.04.010

[6] Bhattacharyya, B.K. and Leu, L.-K. (1975) Spectral Analysis of Gravity and Magnetic Anomalies Due to Two-Dimensional Structures. Geophysics, 40, 993-1013. https://doi.org/10.1190/1.1440593

[7] Spector, A. and Grant., F.S. (1970) Statistical Models for Interpreting Aeromagnetic Data. Geophysics, 35, 293-302. https://doi.org/10.1190/1.1440092

[8] Okubo, Y., Graf, J.R., Hansen, R.O., Ogawa, K. and Tsu, H. (1985) Curie Point Depths of the Island of Kyushu and Surrounding Areas, Japan. Geophysics, 53, 481-494. https://doi.org/10.1190/1.1441926

[9] Bouligand, C., Glen, J.M.G. and Blakely, R.J. (2009) Mapping Curie Temperature Depth in the Western United States with a Fractal Model for Crustal Magnetization. Journal of Geophysical Research, 114, 1-25. https://doi.org/10.1029/2009JB006494

[10] Mickus, K. (1989) Backus and Gilbert Inversion of Two and One-Half Gravity and Magnetic Anomalies and Crustal Structure Studies in Western Arizona and Southeastern California. Ph.D. Dissertation, University of Texas at El Paso, El Paso, TX.

[11] Hussein, M., Mickus, K. and Serpa, L. (2012) Curie Point Depth Estimates from Aeromagnetic Data from Death Valley and Surrounding Regions, California. Pure and Applied Geophysics, 170, 617-632. https://doi.org/10.1007/s00024-012-0557-6

[12] Mickus, K. and Hussein, M. (2015) Curie Depth Analysis of the Salton Sea Region, Southern California Pure and Applied Geophysics, 172, 1383-1780.

[13] Ravat, D., Pignatelli, A., Nicolosi, I. and Chiappini, M. (2007) A Study of Spectral 
Methods of Estimating the Depth to the Bottom of Magnetic Sources from Near-Surface Magnetic Anomaly Data. Geophysical Journal International, 169, 421-434. https://doi.org/10.1111/j.1365-246X.2007.03305.x

[14] Toteu, S.F., Penaye, J. and Djomani, Y.P. (2004) Geodynamic Evolution of the Pan-African Belt in Central Africa with Special Reference to Cameroon. Canadian Journal of Earth Sciences, 41, 73-85. https://doi.org/10.1139/e03-079

[15] Ngoh, J.D., Ndougsa Mbarga, T., Assembe, S.P., Meying, A., Owono Amougou, O.U.I. and Tabod, C.T. (2017) Evidence of Structural Facts Inferred from Aeromagnetic Data Analysis over the Guider-Maroua Area (Northern Cameroon). International Journal of Geosciences, 8, 781-800. https://doi.org/10.4236/ijg.2017.86044

[16] Pauken, R., Thompson, J., Schumann, J. and Cooke, J. (1991) Geology of the Douala Basin, Offshore Cameroon, West Africa. American Association of Petroleum Geologists Bulletin, 75, CONF-910403. https://doi.org/10.1306/0C9B0AA3-1710-11D7-8645000102C1865D

[17] Biyiha-Kelaba, W., Ndougsa-Mbarga, T., Yene-Atangana, P. and Tabod, T. (2013) 2.5 D Models Derived from the Magnetic Anomalies Obtained by Upwards Continuation in the Mimbi Area, Southern Cameroon. Journal of Earth Science and Geotechnical Engineering, 4, 171-199.

[18] Genik, G.J. (1992) Regional Framework, Structural and Petroleum Aspects of Rift Basins in Niger, Chad and the Central African Republic (C.A.R.). Tectonophysics, 213, 169-185. https://doi.org/10.1016/0040-1951(92)90257-7

[19] Tadjou, J., Nouayou, R., Kamguia, J., Houetchack, L. and Manguelle-Dicoum, E. (2009) Gravity Analysis of the Boundary between the Congo Craton and the Pan-African Belt of Cameroon. Austrian Journal of Earth Sciences, 102, 71-79.

[20] Elsheikh, A., Gao, S. and Liu, K. (2014) Formation of the Cameroon Volcanic Line by Lithospheric Basal Erosion: Insight from Mantle Seismic Anisotropy. Journal of African Earth Sciences, 100, 96-108. https://doi.org/10.1016/j.jafrearsci.2014.06.011

[21] De Plaen, R., Bastow, I., Chambers, E., Keir, D., Gallacher, R. and Keane, J. (2014) The Development of Magmatism along the Cameroon Volcanic Line: Evidence from Seismicity and Seismic Anisotropy. Journal of Geophysical Research, 119, 4233-4252. https://doi.org/10.1002/2013JB010583

[22] Fairhead, J.D. (1988) Mesozoic Plate Tectonic Reconstructions of the Central South Atlantic Ocean: The Role of the West and Central African Rift System. Tectonophysics, 155, 188-191. https://doi.org/10.1016/0040-1951(88)90265-X

[23] Guiraud, R., Bosworth, W., Thierry, J. and Delplanque, A. (2005) Phanerozoic Geological Evolution of Northern and Central Africa: An Overview. Journal of African Earth Sciences, 43, 83-143. https://doi.org/10.1016/j.jafrearsci.2005.07.017

[24] Marzoli, A., Piccirillo, E., Renne, P., Bellieni, G., Iacumin, M., Nyobe, J. and Tongwa, A. (2000) The Cameroon Volcanic Line Revisted: Petrogenesis of Continental Basaltic Magmas from Lithospheric and Asthenospheric Mantle Sources. Journal of Petrology, 41, 87-109. https://doi.org/10.1093/petrology/41.1.87

[25] Reusch, A., Nyblade, A., Wiens, D., Shore, P., Ateba, B., Tabod, C. and Nnange, J. (2010) Upper Mantle Structure Beneath Cameroon from Body Wave Tomography and the Origin of the Cameroon Volcanic Line. Geochemistry, Geophysics and Geosystems, 11, W1007. https://doi.org/10.1029/2010GC003200

[26] Ngako, V., Affaton, P. and Njonfang, E. (2008) Pan-African Tectonics in Northwestern Cameroon Implication for the History of Western Gondwana. Gondwana Research, 14, 509-522. https://doi.org/10.1016/j.gr.2008.02.002 
[27] Liégeois, J.P., Black, R., Navez, J. and Latouche, L. (1994) Early and Late Pan-African Orogenies in the Air Assembly of Terranes (Tuareg Shield, Niger). Precambrian Research, 67, 59-88. https://doi.org/10.1016/0301-9268(94)90005-1

[28] Abdelsalam, M.G., Liégeois, J.-P. and Stern, R.J. (2002) The Saharan Metacraton. Journal of African Earth Sciences, 34, 119-136. https://doi.org/10.1016/S0899-5362(02)00013-1

[29] Toteu, S.F., Penaye, J., Deloule, E., Van Schmus, W.R. and Tchameni, R. (2006) Diachronous Evolution of Volcano-Sedimentary Basins North of the Congo Craton: Insights from U-Pb Ion Microprobe Dating of Zircons from the Poli, Lom and Yaoundé Groups (Cameroon). Journal of African Earth Sciences, 44, 428-442. https://doi.org/10.1016/j.jafrearsci.2005.11.011

[30] Penaye, J., Kröner, A., Toteu, S.F., Van Schmus, W.R. and Doumnang, J.C. (2006) Evolution of the Mayo Kebbi Region as Revealed by Zircon Dating: An Early (CA. $740 \mathrm{Ma}$ ) Pan-African Magmatic Arc in Southwestern Chad. Journal of African Earth Sciences, 44, 530-542. https://doi.org/10.1016/j.jafrearsci.2005.11.018

[31] Van Schmus, W.R., Oliveira, E.P., Da Silva Filho, A.F., Toteu, S.F., Penaye, J. and Guimarães, I.P. (2008) Proterozoic Links between the Borborema Province, NE Brazil, and the Central African Fold Belt. Geological Society(London), 294, 69-99. https://doi.org/10.1144/SP294.5

[32] Ngako, V. and Njonfang, E. (2011) Plates Amalgamation and Plate Destruction, the Western Gondwana History. In: Closson, D., Ed., Tectonics, InTech, UK, 3-34.

[33] Moïse, B., Hell, J.V., Samankassou, E., Feist-Burkhardt, S., Eyong, J.T., Ngos, S., Nolla, J.D., Mbesse, C.O., Adatte, T., Mfoumbeng, M.P., Dissombo, E.A.N., Ntsama, A.J., Mouloud, B. and Ndjeng, E. (2018) Hydrocarbon Potential, Palynology and Palynofacies of Four Sedimentary Basins in the Benue Trough, Northern Cameroon. Journal of African Earth Sciences, 139, 73-95.

https://doi.org/10.1016/j.jafrearsci.2017.11.012

[34] Ngako, V., Njonfang, E., Aka, F., Affaton, P. and Nnange, J. (2006) The North-South Paleozoic to Quaternary Trend of Alkaline Magmatism from Niger-Nigeria to Cameroon: Complex Interaction between Hotspots and Precambrian Faults. Journal of African Earth Sciences, 45, 241-256. https://doi.org/10.1016/j.jafrearsci.2006.03.003

[35] Shuey, R.T., Schellinger, D.K., Tripp, A.C. and Alley, L.B. (1977) Curie Depth Determination from Aeromagnetic Spectra. Geophysical Journal of the Royal Astronomical Society, 50, 75-101. https://doi.org/10.1111/j.1365-246X.1977.tb01325.x

[36] Helaly, S.A. (2019) Imaging the Curie Point Isothermal Surface and Predicting Its Impact on the Geothermal Regime within the Nile Delta, Egypt. Egyptian Journal of Petroleum, 28, 77-90. https://doi.org/10.1016/j.ejpe.2018.11.003

[37] Mono, J.A., Ndougsa-Mbarga, T., Tarek, Y., Ngoh, J.D. and Owono Amougou, O.U.I. (2018) Estimation of Curie-Point Depths, Geothermal Gradients and Near-Surface Heat Flow from Spectral Analysis of Aeromagnetic Data in the Loum-Minta Area (Centre-East Cameroon). Egyptian Journal of Petroleum, 27, 1291-1299. https://doi.org/10.1016/j.ejpe.2018.07.002

[38] Haggerty, S.E. (1978) Mineralogical Constraints on Curie Isotherms in Deep Crustal Magnetic Anomalies. Geophysical Research Letters, 5, 105-108. https://doi.org/10.1029/GL005i002p00105

[39] Maden, N. (2010) Curie-Point Depth from Spectral Analysis of Magnetic Data in Erciyes Stratovolcano (Central Turkey). Pure and Applied Geophysics, 167, 349-358. https://doi.org/10.1007/s00024-009-0017-0 
[40] Turcotte, D.L. and Schubert, G. (1982) Geodynamics Applications of Continuum Physics to Geologic Problems. Wiley, New York, 450 p.

[41] Stacey, F.D. and Banerjee, S.K. (1974) The Physical Principles of Rock Magnetism. Elsevier, Amsterdam, 195 p.

[42] Frost, B.R. and Shive, P.N. (1986) Magnetic Mineralogy of the Lower Continental Crust. Journal of Geophysical Research, 91, 6513-6521. https://doi.org/10.1029/JB091iB06p06513

[43] Okubo, Y., Tsu, H. and Ogawa, K. (1989) Estimation of Curie Point Temperature and Geothermal Structure of Island Arcs of Japan. Tectonophysics, 159, 279-290. https://doi.org/10.1016/0040-1951(89)90134-0

[44] Nwankwo, L. and Shehu, A. (2015) Evaluation of Curie-Point Depths, Geothermal Gradients and Near-Surface Heat Flow from High-Resolution Aeromagnetic (HRAM) Data of the Entire Sokoto Basin, Nigeria. Journal of Volcanology and Geothermal Research, 305, 45-55. https://doi.org/10.1016/j.jvolgeores.2015.09.017

[45] Khojamli, A., Ardejani, F., Moradzadeh, A., Kalate, A., Kahoo, A. and Porkhial, S. (2016) Estimation of Curie Point Depths and Heat Flow from Ardebil Province, Iran, Using Aeromagnetic Data. Arabian Journal of Geosciences, 9, 383-393. https://doi.org/10.1007/s12517-016-2400-3

[46] Kasidi, S. and Nur, A. (2012) Curie Depth Isotherm Deduced from Spectral Analysis of Magnetic Data over Sarti and Environs of North-Eastern Nigeria. School Journal of Biotechnology, 1, 49-56.

[47] Eyike, A., Werner, S.C., Ebbing, J. and Dicoum, E.M. (2010) On the Use of Global Potential Field Models for Regional Interpretation of the West and Central African Rift System. Tectonophysics, 492, 25-39. https://doi.org/10.1016/j.tecto.2010.04.026

[48] Rankenburg, K., Lassiter, J.C. and Brey, G. (2004) Origin of Megacrysts in Volcanic Rocks of the Cameroon Volcanic Chain-Constraints on Magma Genesis and Crustal Contamination. Contributions to Mineralogy and Petrology, 147, 129-144. https://doi.org/10.1007/s00410-003-0534-2

[49] Kurowska, E. and Schoeneich, K. (2010) Geothermal Exploration in Nigeria. In: Proceedings of the World Geothermal Congress, Bali, Indonesia, 25-29.

[50] Domra, K.J., Djongyang, N., Danwé, R., Njandjock, N.P., Robert, N., Tabod, C.T. and Oumarou, S. (2015) Geophysical Investigation of Low Enthalpy Geothermal Potential and Ground Water Reservoirs in the Sudano-Sahelian Region of Cameroon. Journal of African Earth Sciences, 44, 81-91. https://doi.org/10.1016/j.jafrearsci.2015.06.007

[51] Saibi, H., Aboud, E. and Masoud, A. (2015) Curie Point Depth Map for Western Afghanistan Deduced from the Analysis of Aeromagnetic Data. Proceedings World Geothermal Congress 2015, Melbourne, Australia, 19-25 April 2015.

[52] Stacey, F.D. (1977) Physics of the Earth. 2nd Edition, Wiley, New York, 414 p.

[53] Jessop, A., Hobart, M. and Sclater, J. (1976) The World Heat Flow Data Collection 1975, Geothermal Services of Canada. Geothermal Service, 50, 55-77. https://doi.org/10.4095/8416

[54] Blackwell, D.D. (1971) The Thermal Structure of the Continental Crust. The Structure and Physical Properties of the Earth's Crust, Geophysical Monograph Series, 14, 169-184. https://doi.org/10.1029/GM014p0169

[55] Cermak, V. and Rybach, L. (1982) Thermal Conductivity and Specific Heat of Minerals and Rocks. Springer-Verlag Publishing, Berlin.

[56] Bansal, A.R., Gabriel, G., Dimri, V.P. and Krawczyk, C.M. (2011) Estimation of 
Depth to the Bottom of Magnetic Sources by a Modified Centroid Method for Fractal Distribution of Sources: An Application to Aeromagnetic Data in Germany. Geophysics, 76, L11-L22. https://doi.org/10.1190/1.3560017 